\title{
Fundusze pożyczkowe w finansowaniu przedsiębiorstw sektora MŚP na przykładzie Funduszu Mikro Sp. z o.o. oddzial w Tarnobrzegu
}

\section{Rola małych i średnich przedsiębiorstw w gospodarce narodowej}

Uzasadnienie dla dynamicznego wzrostu liczby małych i średnich przedsiębiorstw w gospodarce rynkowej znajdujemy w sformułowanej przez J. Schumpetera tezie o „kreatywnej destrukcji”, zgodnie z którą kapitalizm nie mógłby istnieć bez ciągłego rodzenia się nowych firm i staczania się starych (Schumpeter 1960). Formowanie się sektora MŚP nie przebiega wszędzie jednakowo, jest warunkowane przez szereg czynników o charakterze zewnętrznym i wewnętrznym. Sektor małych i średnich przedsiębiorstw w Polsce wprawdzie boryka się z wieloma barierami rozwoju, jednak nie uniemożliwia mu to pełnienia zarówno funkcji gospodarczych, jak i społecznych. B. Piasecki wymienia szereg działań, które podejmuje sektor MŚP w sferze gospodarczej. Są to:

- aktywny udział w procesie zmian w strukturze przemysłowej kraju (inicjowanie powstawania i rozwoju nowych dziedzin produkcji i nowych rodzajów usług, w tym również tych, które z wielu powodów nie były rozwijane w okresie gospodarki centralnie planowanej),

- odgrywanie ważnej roli w formowaniu się prywatnej własności środków produkcji (przejęcie i produkcyjne zagospodarowanie części maszyn i wyposażenia prywatyzowanych wielkich państwowych przedsiębiorstw i wydzielenie z nich wielu mniejszych jednostek, co sprzyja dekoncentracji i demonopolizacji gospodarki kraju),

- wchłonięcie i zagospodarowanie znacznych zasobów siły roboczej, uwolnionej w wyniku racjonalizacji funkcjonowania sektora publicznego,

- zbudowanie koniecznej dla efektywnego funkcjonowania całego systemu gospodarczego ekonomicznej infrastruktury, zwłaszcza rozwój kooperacji i systemu podwykonawstwa,

- wymuszenie zmian w prawnych uregulowaniach sprzyjających przedsiębiorczości i efektywności funkcjonowania małych podmiotów gospodarczych (Piasecki 2001).

I. Czaja podkreśla, że małe i średnie przedsiębiorstwa w procesie rozwoju gospodarki pełnią ponadto inne role: stanowią źródło informacji, niwelują wielkość wahań ekonomicznych, ułatwiają życie konsumentom, równoważą wpływy dużych firm, zagospodarowują nisze na rynku (Targalski 1999). Regionalna decentralizacja dotycząca sektora MŚP oznacza, że lokalizacja podmiotów gospodarczych następuje w każdym miejscu regionu, również tam, gdzie dużym przedsiębiorstwom to się nie opłaca. Ta funkcja małych i średnich przedsiębiorstw przyczynia się także do ograniczania tendencji monopolistycznych w gospodarce (Safin 2003). 
Z punktu widzenia tzw. efektu produkcyjnego o znaczeniu sektora MŚP w gospodarce przesądzają nie tyle względy efektywnościowe, ile charakterystyki ilościowe. W 2007 r. udział MŚP w tworzeniu produktu krajowego brutto wyniósł 47,4\%, w tym mikroprzedsiębiorstw - 30,1\%, małych przedsiębiorstw - 7,3\%, zaś średnich - 10,0\% (Raport 2009). Cechą charakterystyczną w działalności MŚP, obserwowaną od wielu lat, jest wyraźnie silniejsze zaangażowanie w działalność importową niż eksportową. Udział MŚP w eksporcie ogółem wyniósł w 2004 r. 44,5\% i zwiększył się o około $0,2 \% \mathrm{w}$ porównaniu z rokiem poprzednim. Dzięki temu zahamowana została tendencja spadkowa udziału MŚP w eksporcie ogółem, która występowała w latach 2002 i 2003. Z kolei udział MŚP w imporcie ogółem zwiększył się z 59,4\% w 2003 r. do 61,8\% w 2004 r. (Raport 2006). W Polsce, podobnie jak w innych krajach Unii Europejskiej, MŚP przeważają głównie w handlu, budownictwie, działalności gastronomiczno-handlowej. Odgrywają podstawową rolę jako dostawcy półfabrykatów, części maszyn i urządzeń oraz jako wykonawcy specjalistycznych usług dla przedsiębiorstw dużych. Jak twierdzi K. Safin, znaczenie MŚP w dziedzinie produkcji nie maleje, a nadchodzący etap zindywidualizowanych potrzeb stanie się domeną młodych firm (Safin 2003).

Funkcje społeczne pełnione przez MŚP polegają m.in. na uformowaniu klas drobnych właścicieli (jako jednego z ważnych składników pluralizmu politycznego i budowy demokratycznych instytucji), łagodzeniu napięć społecznych i redukcji wysokich społecznych kosztów procesu transformacji poprzez pochłanianie nadwyżek siły roboczej, promowanie samozatrudnienia, wskazywanie możliwości osiągnięcia sukcesu i zmiany statusu społecznego (Piasecki 1998). Korzystny wpływ sektora MŚP na efekty zatrudnienia ma wymiar wielowątkowy (Raport 2006; Safin 2003; Małecka 1999; Kożuch, Plawgo 1999; Bielawska 1992; Raport 2009):

- znaczenie MŚP jako pracodawcy odzwierciedlają dane statystyczne - w 2007 r. liczba pracujących ogółem w przedsiębiorstwach wyniosła 8,969 tys. osób, z czego nieco ponad 69\% pracowało w przedsiębiorstwach sektora MŚP,

- MŚP wnoszą duży wkład w tworzenie nowych miejsc pracy w obszarach trudnych do zagospodarowania i dają większą pewność ich utrzymania niż duże przedsiębiorstwa,

- MŚP mają poważny udział w systemie szkolenia i kształcenia zawodowego,

- małe przedsiębiorstwa generują niższy poziom bezrobocia, co związane jest m.in. z tym, że są one wierne pierwotnej lokalizacji,

- małe i średnie przedsiębiorstwa nie zatrudniają pracowników najemnych (ok. 31\%); oznacza to, że samozatrudnienie jest w poważnej części źródłem nowych miejsc pracy,

- niezbędne nakłady finansowe na utworzenie jednego miejsca pracy w małej firmie są kilkakrotnie niższe niż w dużych przedsiębiorstwach.

Małe i średnie przedsiębiorstwa poprzez pozytywne efekty swojej działalności (np. nowa inwestycja, produkcja, bogacenie się właścicieli) przyczyniają się do tworzenia pozytywnego obrazu przedsiębiorcy, kształtowania postaw przedsiębiorczych i wzrostu odpowiedzialności za własny los (Safin 2003).

\section{Źródla finansowania przedsiębiorstw sektora MŚP}

Istotę gospodarki finansowej przedsiębiorstw stanowi pozyskanie kapitału, sterowanie nim (administrowanie) i stosowanie go w sposób prawidłowy (Łuczka 1997). Korzystanie z kapitału obcego wynika $\mathrm{z}$ faktu niedysponowania przez podmioty gospodarcze własnymi środkami w pełni finansującymi bieżące i inwestycyjne przedsięwzięcia. Wybór źródeł finansowania jest uzależniony w dużym stopniu od hierarchii metod finansowania stosowanej przez MŚP oraz kryteriów, mówiących o atrakcyjności poszczególnych źródeł dla przedsiębiorstw. W odniesieniu do MŚP zastosowanie ma teoria hierarchii źródeł finansowania, stworzona przez 
S.C. Myersa. Zakłada ona, że przedsiębiorstwa wybierają źródła finansowania według określonej kolejności, nie starają się przy tym maksymalizować wartości firmy. Teoria ta wskazuje, że przedsiębiorstwa preferują wewnętrzne źródła finansowania. Dopiero w wypadku braku w wystarczającym stopniu źródeł wewnętrznych sięgają po środki zewnętrzne. Wybierając środki zewnętrzne, kierują się kolejnością jak najmniejszego uzależnienia od podmiotu, który je przyznaje (Wolański 2009).

Na pytanie, dlaczego przedsiębiorstwa korzystają z takich, a nie innych źródeł, można odpowiedzieć na podstawie kryteriów atrakcyjności poszczególnych źródeł finansowania. Jednak przy ich ustalaniu bierze się pod uwagę cechy samych źródeł, nie zaś postawę przedsiębiorstw. Można wyróżnić następujące kryteria oceny atrakcyjności poszczególnych źródeł finansowania (Kubiak 2005, Wolański 2009):

- dostępność - zależy od wymagań stawianych MŚP przez źródło finansowania; przedsiębiorstwo musi spełnić warunki określone przez udzielającego wsparcia finansowego (tab. 1),

- koszt - przedsiębiorstwa dążą do jego minimalizowania,

- elastyczność - oznacza szybkość pozyskania źródła, wielkość dostępnych środków, czas spłaty, łatwość zmniejszania i zwiększania wartości zadłużenia, możliwość renegocjacji terminu spłaty.

Tab. 1. Dostępność źródeł finansowania dla małych i średnich przedsiębiorstw

\begin{tabular}{|c|c|c|c|c|}
\hline \multicolumn{5}{|c|}{ Źródla finansowania } \\
\hline $\begin{array}{l}\text { dostępne przede } \\
\text { wszystkim dla } \\
\text { MŚP }\end{array}$ & $\begin{array}{l}\text { bardziej dostępne } \\
\text { dla MŚP niż } \\
\text { dla dużych } \\
\text { przedsiębiorstw }\end{array}$ & $\begin{array}{c}\text { jednakowo } \\
\text { dostępne dla } \\
\text { wszystkich } \\
\text { przedsiębiorstw }\end{array}$ & $\begin{array}{l}\text { bardziej dostępne } \\
\text { dla dużych } \\
\text { przedsiębiorstw } \\
\text { niż dla MŚP }\end{array}$ & $\begin{array}{l}\text { dostępne przede } \\
\text { wszystkim } \\
\text { dla dużych } \\
\text { przedsiębiorstw }\end{array}$ \\
\hline $\begin{array}{l}\text { - poręczenia } \\
\text { kredytowe } \\
\text { - środki unijne } \\
\text { - pożyczki od } \\
\text { funduszy } \\
\text { pożyczkowych }\end{array}$ & $\begin{array}{l}\text { - dotacje budżetowe } \\
\text { - pożyczki od } \\
\text { rodziny i znajo- } \\
\text { mych }\end{array}$ & $\begin{array}{l}\text { - środki własne } \\
\text { - kredyty } \\
\text { bankowe } \\
\text { krótko- } \\
\text { terminowe } \\
\text { - leasing } \\
\text { - kredyty od } \\
\text { dostawców } \\
\text { - franchising }\end{array}$ & $\begin{array}{l}\text { - kredyty bankowe } \\
\text { długoterminowe } \\
\text { - kredyty od } \\
\text { odbiorców } \\
\text { - fundusze venture } \\
\text { capital } \\
\text { - factoring } \\
\text { - emisje na rynku } \\
\text { pozagiełdowym }\end{array}$ & $\begin{array}{l}\text { - } \text { emisje obligacji } \\
\text { - emisje na rynku } \\
\text { giełdowym }\end{array}$ \\
\hline
\end{tabular}

Źródło: Wolański 2009, s. 81.

Na strategię finansowania przedsiębiorstw wpływają różne wymierne i niewymierne czynniki. Składają się na nią zarówno czynniki zależne od przedsiębiorstwa (wewnętrzne), jak i czynniki niezależne od niego (zewnętrzne). Do czynników wewnętrznych zalicza się m.in. cel i charakter prowadzonej działalności, skalę działalności, fazę rozwoju, w której znajduje się przedsiębiorstwo, perspektywy rozwoju przedsiębiorstwa, ryzyko gospodarcze, elastyczność finansową, strukturę posiadanego majątku, kondycję finansową, umiejętności kadr, zdolności produkcyjne. Na czynniki zewnętrzne składają się takie elementy, jak: polityka gospodarcza, komunikacja gospodarcza, obowiązujące przepisy prawne (głównie podatkowe), zakres dostępnych usług finansowych, warunki na rynku kapitałowym, trendy rozwojowe w danym dziale (Michalczuk 2000). Zatem czynniki występujące w otoczeniu oraz wewnątrz przedsiębiorstwa tworzą układ szans i zagrożeń dla wszystkich podmiotów działających w gospodarce. 
Wiedza na temat struktury i powiązań elementów otoczenia oraz kierunków zmian, określenie przewidywanych zmian i szacowanie ich skutków warunkuje trafny wybór decyzji w zakresie finansowania przedsiębiorstw, ich bieżącej działalności i rozwoju (Grzywacz, Okońska 2005).

Głównym źródłem finansowania małych i średnich przedsiębiorstw pozostają niezmiennie od lat własne środki pieniężne właściciela, generowany przez podmiot gospodarczy zysk i pożyczki z sektora pozabankowego. Wynika to m.in. z badań przeprowadzonych w 2008 r. na zlecenie Polskiej Agencji Rozwoju Przedsiębiorczości, poświęconych działalności inwestycyjnej sektora MŚP. Do podstawowych instrumentów finansowania działalności inwestycyjnej w 2007 r. wykorzystywane były: środki własne (tak deklarowało 94\% badanych przedsiębiorstw), kredyty i pożyczki krajowe (29\%), środki publiczne (3\%) (Raport 2008). Zbieżne dane na ten temat prezentują także najnowsze badania dotyczące funkcjonowania małych i średnich przedsiębiorstw wykonane dla Polskiej Konfederacji Pracodawców Prywatnych Lewiatan (tab. 2).

Tab. 2. Sposób finansowania inwestycji przez małe i średnie przedsiębiorstwa

\begin{tabular}{|l|c|c|c|}
\hline \multirow{2}{*}{\multicolumn{1}{c}{ Źródła finansowania inwestycji }} & \multicolumn{3}{|c|}{ Odsetek MŚP korzystających ze źródła } \\
\cline { 2 - 4 } & $\mathbf{2 0 0 5}$ & $\mathbf{2 0 0 6}$ & $\mathbf{2 0 0 7}$ \\
\hline Środki własne (w tym zysk zatrzymany) & $69,1 \%$ & $73,1 \%$ & $72,6 \%$ \\
\hline Kredyt bankowy & $16,6 \%$ & $12,7 \%$ & $17,4 \%$ \\
\hline Leasing & $10,5 \%$ & $9,0 \%$ & $6,9 \%$ \\
\hline Fundusze unijne & $1,4 \%$ & $1,9 \%$ & $1,9 \%$ \\
\hline Inne & $2,4 \%$ & $3,3 \%$ & $1,2 \%$ \\
\hline
\end{tabular}

Źródło: Starczewska-Krzystoszek 2008, s. 16.

Przyjęty sposób finansowania przez MŚP ma charakter konserwatywny i determinowany jest kilkoma czynnikami. Wydaje się, że najważniejszym z nich jest awersja do ryzyka związanego z korzystaniem ze środków obcych. Małe i średnie przedsiębiorstwa to w większości firmy rodzinne i decyzja o rozwoju opartym na obcym kapitale oznacza narażenie firmy na wyższe ryzyko, a tym samym na możliwość utraty firmy (bankructwo, przejęcie), a w konsekwencji - utratę miejsca pracy i dochodu. Drugim czynnikiem są koszty pozyskania kredytów. Nie chodzi tylko o prowizje i odsetki, ale także o koszt zabezpieczeń kredytów. Przedsiębiorstwa małe i średnie nie dysponują bowiem aktywami o wysokiej wartości, które mogłyby stanowić zabezpieczenie dla zaciąganych przez nie kredytów (Starczewska-Krzysztoszek 2008). Stąd przeciwdziałać takiemu stanowi rzeczy mają te instrumenty finansowania zewnętrznego, które adresowane są przede wszystkim do sektora MŚP. Mowa tu o środkach unijnych i budżetowych, pożyczkach i poręczeniach udzielanych przez fundusze pożyczkowe i poręczeniowe. Dla przykładu, stabilne fundusze pożyczkowe (FP), działające sprawnie w gospodarce, stały się idealnym partnerem dla Polskiej Agencji Rozwoju Przedsiębiorczości w niesieniu pomocy przedsiębiorcom, którzy ucierpieli podczas powodzi w roku 2001. W ramach tej współpracy, w ośmiu województwach nawiedzonych przez powódź, 10 funduszy pożyczkowych udzielało pożyczek 
na odtworzenie utraconego przez przedsiębiorców majątku. Rola funduszy pożyczkowych wraz z upływem czasu ewoluuje. Fundusze pożyczkowe dywersyfikują produkty finansowe i oferują dodatkowe usługi komplementarne, jak: szkolenia, doradztwo i konsultacje (Forin i inni 2010).

Głównym celem niniejszego artykułu jest przedstawienie opinii przedsiębiorców - klientów funduszu pożyczkowego: Fundusz Mikro Sp. z o.o. oddział w Tarnobrzegu (FM) na temat otrzymanych usług pożyczkowych i ich wpływu na funkcjonowanie przedsiębiorstw. Fundusz Mikro Sp. z o.o. jest niekomercyjną instytucją, która zaspokaja zapotrzebowanie na środki finansowe wyłącznie mikroprzedsiębiorców. Corocznie udziela ponad 230 pożyczek przedsiębiorcom, którzy nie spełniają warunków stawianych przez banki komercyjne. Wymagania kierowane do potencjalnych klientów FM dotyczą formy organizacyjno-prawnej i opodatkowania, struktury zatrudnienia oraz wskazania celu, na który zostanie udzielona pożyczka (Buś-Bidas 2006).

Charakteryzując portfel pożyczkowy tarnobrzeskiego oddziału Funduszu Mikro od początku działalności do 31.12.2008 r., należy wskazać, iż wyróżniał się on nie tylko liczbą udzielonych pożyczek, ale także ich całkowitą wartością. Udzielił prawie czterokrotnie więcej pożyczek niż łącznie pozostałe instytucje finansujące funkcjonujące w powiecie tarnobrzeskim oraz stalowowolskim, a całkowita wartość udzielonych pożyczek była blisko dwukrotnie wyższa od sumy wartości pożyczek biura obsługi klienta Inicjatywy Mikro i funduszu pożyczkowego przy Regionalnej Izbie Gospodarczej (Buś-Bidas 2009).

\section{Usługi pożyczkowe Funduszu Mikro Sp. z o.o. w opinii przedsiębiorców}

Mikroprzedsiębiorcy działający na terenie powiatu tarnobrzeskiego, sandomierskiego, stalowowolskiego stanowią ważnych odbiorców usług świadczonych przez instytucję pożyczkową. Stąd poproszeni zostali o wyrażenie swoich poglądów na tematy związane z podażową stroną rynku instrumentów finansowych. Prezentacja zbiorowości badawczej, składającej się z 35 przedsiębiorców została dokonana z uwzględnieniem poniższych kryteriów.

- Kryterium 1 - rodzaj prowadzonej działalności gospodarczej (tab. 3).

Tab. 3. Liczba/struktura badanych przedsiębiorstw według rodzaju prowadzonej działalności gospodarczej

\begin{tabular}{|l|c|c|}
\hline \multicolumn{1}{|c|}{ Rodzaj prowadzonej działalności gospodarczej } & \multicolumn{2}{c|}{ Liczba i odsetek przedsiębiorstw } \\
\hline Przemysł & 3 & $8,6 \%$ \\
\hline Budownictwo & 3 & $8,6 \%$ \\
\hline Handel i naprawy & 43 & $37,0 \%$ \\
\hline Transport, gospodarka magazynowa i łączność & 2 & $11,4 \%$ \\
\hline Pośrednictwo finansowe & 2 & $5,7 \%$ \\
\hline Obsługa nieruchomości i firm & 8 & $5,7 \%$ \\
\hline $\begin{array}{l}\text { Działalność usługowa społeczna, indywidualna } \\
\text { i pozostała }\end{array}$ & 35 & $23,0 \%$ \\
\hline Ogółem & & $100,0 \%$ \\
\hline
\end{tabular}

Źródło: opracowanie własne ma podstawie badań ankietowych. 
Największa liczba przedsiębiorstw działała w sekcji handel i naprawy. Była to grupa licząca 13 podmiotów gospodarczych, tj. 37,0\% ogółu ankietowanych. Przedsiębiorstwa z branży przemysł oraz budownictwo stanowiły łącznie 17,2\%. W badanej zbiorowości nie stwierdzono przedsiębiorstw z sekcji rolnictwo, łowiectwo i leśnictwo, hotele i restauracje czy ochrona zdrowia.

- Kryterium 2 - forma organizacyjno-prawna podmiotu gospodarczego (tab. 4).

Tab. 4. Liczba/struktura badanych przedsiębiorstw według formy organizacyjno-prawnej

\begin{tabular}{|l|c|c|}
\hline Forma organizacyjno-prawna przedsiębiorstwa & \multicolumn{2}{|c|}{ Liczba i odsetek przedsiębiorstw } \\
\hline Osoba fizyczna prowadząca działalność gospodarczą & 34 & $97,1 \%$ \\
\hline Spółka z ograniczoną odpowiedzialnością & 1 & $2,9 \%$ \\
\hline Ogółem & 35 & $100,0 \%$ \\
\hline
\end{tabular}

Źródło: opracowanie własne ma podstawie badań ankietowych.

Spośród 35 badanych przedsiębiorstw 34 było osobami fizycznymi prowadzącymi działalność gospodarczą. Jeden przedsiębiorca funkcjonował jako spółka z ograniczoną odpowiedzialnością.

- Kryterium 3 - okres prowadzenia działalności gospodarczej (tab. 5).

Tab. 5. Liczba/struktura badanych przedsiębiorstw według długości czasu prowadzenia działalności gospodarczej

\begin{tabular}{|l|c|c|}
\hline \multicolumn{1}{|c|}{ Okres prowadzenia działalności gospodarczej } & \multicolumn{2}{c|}{ Liczba i odsetek przedsiębiorstw } \\
\hline Krócej niż rok & 0 & $0,0 \%$ \\
\hline Od 1 roku do 3 lat & 4 & $11,4 \%$ \\
\hline Od 3 do 5 lat & 8 & $23,0 \%$ \\
\hline Od 5 do 10 lat & 10 & $28,6 \%$ \\
\hline Powyżej 10 lat & 13 & $37,0 \%$ \\
\hline Ogółem & 35 & $100,0 \%$ \\
\hline
\end{tabular}

Źródło: opracowanie własne ma podstawie badań ankietowych.

Najliczniejsza była grupa przedsiębiorstw, które funkcjonowały na rynku dłużej niż 5 lat. Tworzyło ją 23 przedsiębiorców, co stanowiło 65,6\% ogółu ankietowanych. Zatem można stwierdzić, że większość podmiotów gospodarczych posiadała już ugruntowaną pozycję na rynku.

Badani przedsiębiorcy wskazywali różnorodne powody sięgania po pożyczki oferowane przez Fundusz Mikro Sp. z o.o. Większość ankietowanych, tj. 65,7\%, skorzystanie z instrumentów finansowych wiązało z realizacją planów rozwojowych. Prawie co drugi przedsiębiorca twierdził, iż do zgłoszenia zapotrzebowania na usługi pożyczkowe zmusił go bieżący problem lub kryzys. W ocenie pracowników FM sytuacja ekonomiczno-finansowa przedsiębiorstw pozwalała jednak na interwencję bez ryzyka, np. niewypłacalności pożyczkobiorcy. Przedsiębiorcy wymienili jeszcze inne przyczyny sięgania po wsparcie finansowe: brak możliwości uzyskania innego zewnętrznego źródła finansowania, brak informacji o istnieniu innych usług finansowych (tab. 6). 
Tab. 6. Liczba/struktura przedsiębiorstw według głównego powodu skorzystania z finansowania funduszu pożyczkowego

\begin{tabular}{|l|c|c|}
\hline \multicolumn{1}{|c|}{ Glówny powód skorzystania z usług pożyczkowych } & \multicolumn{2}{c|}{ Liczba i odsetek przedsiębiorstw } \\
\hline Przedsiębiorstwo przeżywało kryzys & 7 & $26,0 \%$ \\
\hline Przedsiębiorstwo borykało się z bieżącym problemem & 12 & $34,3 \%$ \\
\hline Przedsiębiorstwo realizowało plany rozwojowe & 23 & $65,7 \%$ \\
\hline $\begin{array}{l}\text { Brak możliwości uzyskania innego zewnętrznego źródła } \\
\text { finansowania }\end{array}$ & 15 & $42,9 \%$ \\
\hline Brak informacji o istnieniu innych usług finansowych & 4 & $11,4 \%$ \\
\hline
\end{tabular}

Źródło: opracowanie własne ma podstawie badań ankietowych.

Badani przedsiębiorcy dokonali oceny usług pożyczkowych, z których skorzystali, uwzględniając siedem następujących kryteriów: dostęp do usług, sposób organizacji usług, polityka cenowa, komunikacja z instytucją pożyczkową, zrozumienie specyfiki przedsiębiorstwa, profesjonalizm pracowników i jakość świadczonych usług. Zdecydowana większość ankietowanych (od 65,7\% do 88,5\% w zależności od rodzaju kryterium) wyraziła swoje zadowolenie z usług finansowych poprzez wystawienie ocen bardzo dobrych i dobrych. Są to czynniki, które wpłynęły na to, że oddział FM był najczęściej wybieraną instytucją finansującą działalność przedsiębiorców w latach 2004-2008. Wyjątek stanowi sytuacja, gdzie tylko 40,0\% respondentów odpowiadały usługi pożyczkowe ze względu na stosowaną politykę cenową, a $26 \%$ badanych oceniło usługi słabo i bardzo słabo (tab. 7). Ten fakt nie dziwi, bowiem wyniki badań przeprowadzonych w 2009 r. dotyczące oferty funduszy pożyczkowych jednoznacznie wskazują, iż prowizje i oprocentowanie od udzielonych pożyczek w analizowanym okresie były najwyższe właśnie w Funduszu Mikro Sp. z o.o. (Buś-Bidas 2009).

Tab. 7. Struktura przedsiębiorstw oceniających usługi pożyczkowe według rożnych kryteriów

\begin{tabular}{|l|c|c|c|c|c|}
\hline \multirow{2}{*}{ Kryterium } & \multicolumn{5}{c|}{ Odsetek przedsiębiorstw oceniających usługi } \\
pożyczkowe (\%)
\end{tabular}

Źródło: opracowanie własne ma podstawie badań ankietowych. 
Zdaniem 80,0\% podmiotów gospodarczych, udzielone wsparcie miało korzystny wpływ na funkcjonowanie przedsiębiorstwa. Co piąty ankietowany przedsiębiorca nie miał sprecyzowanego poglądu na ten temat. Nie odnotowano przypadku niekorzystnego wpływu otrzymanych usług pożyczkowych na działalność badanych podmiotów gospodarczych i braku wpływu otrzymanej pomocy ze strony instytucji finansowej.

Najczęściej wymienianymi korzyściami, które przyniosły ankietowanym przedsiębiorstwom świadczone usługi pożyczkowe, były: poszerzenie bazy lokalowej (51,4\%), realizacja inwestycji rozwojowej $(48,6 \%)$. Kolejnymi pozytywnymi efektami otrzymanego wsparcia było rozszerzenie rynku zbytu w kraju/za granicą (34,3\%), komputeryzacja przedsiębiorstwa $(31,4 \%)$. Wskazać można także przykłady, gdzie tego typu pomoc finansowa miała wpływ na: powstanie nowych miejsc pracy, wdrożenie nowej technologii, podniesienie kwalifikacji kadry zarządzającej/pracowników czy poprawę jakości wyrobów/usług (tab. 8).

Tab. 8. Liczba/struktura przedsiębiorstw według wskazania rodzaju korzyści z otrzymanego wsparcia

\begin{tabular}{|l|c|c|}
\hline \multicolumn{1}{|c|}{ Korzyści z otrzymanego wsparcia } & \multicolumn{2}{c|}{ Liczba i odsetek przedsiębiorstw } \\
\hline Powstanie nowych miejsc pracy & 8 & $22,9 \%$ \\
\hline Wdrożenie nowej technologii & 7 & $20,0 \%$ \\
\hline Podniesienie kwalifikacji kadry zarządzającej/pracowników & 5 & $14,2 \%$ \\
\hline Rozszerzenie rynku zbytu w kraju/za granicą & 12 & $34,3 \%$ \\
\hline Realizacja inwestycji rozwojowej & 17 & $48,6 \%$ \\
\hline Wprowadzenie systemu zarządzania & 0 & $0,0 \%$ \\
\hline Poszerzenie bazy lokalowej & 18 & $51,4 \%$ \\
\hline Obniżenie kosztów działalności & 0 & $0,0 \%$ \\
\hline Poprawa jakości wyrobów/usług & 4 & $11,4 \%$ \\
\hline Komputeryzacja przedsiębiorstwa & 11 & $31,4 \%$ \\
\hline
\end{tabular}

Źródło: opracowanie własne ma podstawie badań ankietowych.

Odwołując się do wyników badań ankietowych pt. Fundusze pożyczkowe i poręczeniowe $w$ finansowaniu małych i średnich przedsiębiorstw w Polsce, przeprowadzonych przez B. Bartkowiak, znajdujemy potwierdzenie, iż decydujący lub duży wpływ funduszy pożyczkowych dotyczy następujących aspektów funkcjonowania i rozwoju mikro-, małych i średnich przedsiębiorstw:

- możliwość finansowania inwestycji, w tym przedsięwzięć charakteryzujących się podwyższonym/wysokim ryzykiem,

- wzmacnianie pozycji rynkowej,

- aktywizowanie bezrobotnych i wsparcie przy zakładaniu nowej działalności gospodarczej,

- przełamywanie barier do finansowania (Bartkowiak 2009).

Z kolei umiarkowane oddziaływanie otrzymały następujące czynniki: komplementarność w stosunku do systemu bankowego i innych źródeł zewnętrznego finansowania, kreowanie dobrej historii kredytowej - stworzenie podwalin pod przyszłą współpracę z sektorem bankowym poprzez mniejsze wymogi dotyczące zabezpieczeń zdolności kredytowej. 
Fundusz Mikro Sp. z o.o. można nazwać inkubatorem finansowym, który przygotowuje przedsiębiorców do efektywnego korzystania w przyszłości z pomocy finansowej systemu bankowego. Okazuje się bowiem, że pozytywne doświadczenia związane z otrzymanymi usługami pożyczkowymi miały wpływ nie tylko na częstotliwość korzystania z pomocy instytucji (77,1\% przedsiębiorców korzystało z usług pożyczkowych od dwu do pięciu razy w ciągu ostatnich sześciu lat), ale także na postawę przedsiębiorców wobec innych zewnętrznych źródeł finansowania. Ankietowani deklarują, iż zamierzają korzystać w szczególności z kredytu bankowego $(74,2 \%)$, dotacji unijnych $(65,7 \%)$ i leasingu $(45,7 \%)$.

\section{Literatura}

1. Bartkowiak B., 2009, Fundusze pożyczkowe i poręczeniowe $w$ finansowaniu matych $i$ średnich przedsiębiorstw w Polsce, Wyd. CeDeWu, Warszawa.

2. Bielawska A., 1992, Znaczenie matych firm dla rozwoju gospodarczego, „Ekonomista”, nr 3, Warszawa.

3. Buś-Bidas A., 2006, Wplyw ustug wspierajacych na lokalne przedsiębiorstwa (na przyktadzie powiatu tarnobrzeskiego), praca doktorska (maszynopis).

4. Buś-Bidas A., 2009, Dostęp do zewnętrznych źródeł finansowania przedsiębiorstw sektora MŚP $w$ powiecie tarnobrzeskim $i$ stalowowolskim, maszynopis.

5. Forin A. i inni, 2010, Przedsiębiorco! Skorzystaj!, Polska Agencja Rozwoju Przedsiębiorczości, Warszawa.

6. Grzywacz J., Okońska A., 2005, Venture capital a potrzeby kapitałowe małych $i$ średnich przedsiębiorstw, Wyd. Szkoły Głównej Handlowej w Warszawie, Warszawa.

7. Kożuch B., Plawgo B., 1999, Wyzwania rozwojowe matych $i$ średnich przedsiębiorstw [w:] Wyzwania rozwojowe a restrukturyzacja przedsiębiorstw, R. Borowiecki (red.), Wyd. Akademii Ekonomicznej w Krakowie, Kraków.

8. Kubiak J., 2005, Hierarchia źródet krótkoterminowego finansowania przedsiębiorstw, Wyd. Akademii Ekonomicznej w Poznaniu, Poznań.

9. Łuczka T., 1997, Kapitat jako przedmiot gospodarki finansowej małego i średniego przedsiębiorstwa prywatnego: wprowadzenie do finansów przedsiębiorstwa, Wydawnictwo Politechniki Poznańskiej, Poznań.

10. Małecka E., 1999, Znaczenie matych firm w okresie transformacji, „Gospodarka w teorii i praktyce”, nr 1(4), Wyd. Uniwersytetu Łódzkiego, Łódź.

11. Michalczuk G., 2000, Determinanty kształtowania strategii finansowej majątku (wyniki badań empirycznych) [w:] Problemy finansów, informatyki i matematyki finansowej, W.L. Jaworski (red.), Wyd. Wyższej Szkoły Finansów i Zarządzania w Białymstoku, Białystok.

12. Piasecki B., 1998, Przedsiębiorczość i mała firma. Teoria i praktyka, Wyd. Uniwersytetu Łódzkiego, Łódź.

13. Piasecki B. (red.), 2001, Ekonomika i zarzadzanie mała firma, Wyd. Naukowe PWN, Warszawa.

14. Raport o stanie sektora matych i średnich przedsiębiorstw w Polsce w latach 2004-2005, 2006, Polska Agencja Rozwoju Przedsiębiorczości, Warszawa.

15. Raport o stanie sektora matych $i$ średnich przedsiębiorstw w Polsce $w$ latach 2006-2007, 2008, Polska Agencja Rozwoju Przedsiębiorczości, Warszawa.

16. Raport o stanie sektora matych i średnich przedsiębiorstw w Polsce w latach 2007-2008, 2009, Polska Agencja Rozwoju Przedsiębiorczości, Warszawa. 
17. Safin K., 2003, Zarządzanie mała firma, Wyd. Akademii Ekonomicznej im. Oskara Langego we Wrocławiu, Wrocław.

18. Schumpeter J., 1960, Teoria rozwoju gospodarczego, PWN, Warszawa.

19. Starczewska-Krzysztoszek M., 2008, Konkurencyjność sektora MŚP 2008 wyniki badania, Polska Konfederacja Pracodawców Prywatnych Lewiatan, Warszawa.

20. Targalski J. (red.), 1999, Przedsiębiorczość i rozwój firmy, Wyd. Akademii Ekonomicznej w Krakowie, Kraków.

21. Wolański R., 2009, Nowe źródła finansowania rozwoju przedsiębiorstw [w:] Raport o stanie sektora matych i średnich przedsiębiorstw w Polsce w latach 2007-2008, Polska Agencja Rozwoju Przedsiębiorczości, Warszawa.

\section{The Loan Funds as the Source of Financing for Enterprises of SMEs Sector on the Example of Mikro Limited Company Fund, Tarnobrzeg Branch}

The article presents the opinions of entrepreneurs - customers of the loan fund concerning the supply of support services. The respondents evaluated loan services and their influence on functioning and development of the enterprises. 